\title{
The Influence of Changes in Sales Culture and Competitive Advantages to Consumer Behavior Online Shop on Covid-19 Pandemic Conditions
}

\author{
Vinnoya Apcaresta Alika \\ Master of Management Student \\ Mercu Buana University \\ Jakarta, Indonesia
}

\author{
Setyo Riyanto \\ Associate Professor \\ Mercu Buana University \\ Jakarta, Indonesia
}

\begin{abstract}
Coronavirus has introduced us to life online. Online Shop development or online store through internet media already mushed in Indonesia. The quality of service that exceeds the expectations of consumers can attract consumer shopping and consumer confidence in the Online Shop is a key point to establish long-term relationship with consumers. The research uses primary data obtained from questionnaires distributed to 75 entrepreneurs affected by COVID-19. This study explains the partial and simultaneous influences between marketing culture variables (X1), competative Excellence (X2), and consumer attitudes (Y). A significant and positive influence and reliable on the use of Sales Culture and Competitive Advantage on Consumer Behavior. This indicates that the Sales Culture (X1) and Competitive Advantage (X2) Usage variables provide a simultaneous effect of $22 \%$ on Consumer Behavior (Y).
\end{abstract}

\section{Keywords:- Sales Culture, Competitive Advantage,} Consumer Behavior.

\section{INTRODUCTION}

Coronavirus has introduced us to life online and does not take for granted face-to-face meetings that once tasted ordinary. It's possible that virtual events and sales with platforms on the Internet are temporary. But perhaps also after spending years using technology that feels to make us split, the coronavirus crisis shows us that the Internet is still able to unite us. That's why it's so important that everyone has access to this electronic device.

The development of Online Shop or online store through internet media already mushed in Indonesia, even already very well known by the public. Many various facilities in shopping and various types of products and services offered, making the people of Indonesia make Online Shop as one of the new "shopping places" in addition to shopping centers. This makes many Online Shop sellers who compete - the competition offers its products in various ways to attract consumers shopping, they take advantage of the circumstances where Online Shopping is currently in demand by the Indonesian people to date. With the high current online shop competition, the concentration of all entrepreneurs is the satisfaction of consumers.
The quality of service that exceeds the expectations of consumers can attract consumer shopping and consumer confidence in the Online Shop is a key point to establish longterm relationship with consumers. Both factors are the main thing that can create customer satisfaction to the Online Shop. According to Akbar and Parvez (2009), the most common interpretation of consumer satisfaction gained from various authors reflects the notion that satisfaction is a feeling resulting from a process of evaluating what has been received against what consumers expect, including the purchase decision itself, the needs of its own consumers, and the desires associated with purchases made by consumers.

Consumers who have been satisfied to shop in the Online Shop, will usually make a purchase back on the same Online Shop. And consumers who have been satisfied, have great potential to recommend the Online Shop where they shop for your brother or relatives. According to Akbar and Parvez (2009), it has defined consumer loyalty as the mindset of consumers who have a good attitude towards the company, committed to re-buying the company's products/services, and recommending products/services to others. According to Akbar and Parvez (2009), as identified by researchers that consumer loyalty as a construction consists of both consumer attitudes and behaviors. The consumer attitudes component is an idea such as: the intention of repurchase or buying an additional product or service from the same company, a willingness to recommend the company to others, proof of such commitment to the company by indicating resistance to switch to another competitor.

The idea of how culture can affect the real behaviour of something that is difficult to observe, because culture is a dynamic and intangible. In dynamic conditions, it becomes harder to see who affects what and how they affect it. This can happen because in a culture of the originality aspect is difficult to find. Suppose we want to see how the cultural influences Bali in the behavior of shopping. Cultural context becomes difficult to determine because Balinese culture is also influenced by Javanese culture, and Javanese culture also influenced by other cultures. Secondly, culture doesn't always seem, and it's hard to measure. Cultural values, and basic assumptions are variables that are difficult to observe. This view is in line with the opinions of Yeniyurt and Townsend (2003), that the culture remains an elusive, multi-faceted look, so it tends to be difficult to understand and use in full. It is also difficult to ensure that consumers when doing a product 
consumption process, are also always accompanied by cultural considerations, or for other more technical reasons. But by trying to expose some of the images and events that occurred and try to combine between the theory and reality that occurred in the observation of the author, tried to explain the role of culture in marketing.

\section{LIBRARY OVERVIEW}

Understanding the culture will help in understanding how others interpret their environment. Culture, can shape people in viewing their world and how it can work in the world. Culture can form personal values, group values and attitudes including in this case what can go well, or do not go well, what can be helpful and not helpful and what gives meaning and which does not give meaning. Culture, provides general guidance to behave and act in certain situations that are accepted by the community. Culture affects how we interact and socialize with other members in a society (Rokeach, 1973). Culture is a powerful tool for building motivation, lifestyle, and product selection.

In marketing, according to Assael (2010) Cultural values are very likely to affect community members in purchasing patterns and consumption patterns. A consumer may give a high value to the culture and marketing achievement and will show success with luxury and prestige. Other consumers will deliver it through a youthful and active impression. Culture not only affects consumer behaviour, culture reflects behavior. Fitness clubs, diets, skin care lotions, and low-fat products, show reflecting American culture that gives attention to the youthful style and attention to fitness. More than that, culture becomes a mirror of both the value and possession of objects by its members.

Changes in cultural values are possible and promoted in the pattern of consumption behaviour and how consumption takes place. In Javanese people, where the wedding reception is a part that is thick with cultural nuance, there is a change in the way of food serving. In big cities such as Jakarta, Surabaya, Bandung, and Jogjakarta, and many other cities, the reception with standing party model has been done a lot. In the past, this kind of reception was hard to accept because eating by standing was considered disrespectful. But now with the development of the Times, where the people are more appreciative time, and eat while standing is not taken as an oddity so that the standing party model is considered the most practical and save time. This can happen because the community receives enough practicality values that are increasingly symptomatic in the community in line with increasingly cultural modernization.

Satisfaction will give birth not only positive information among the consumers of retail goodness. If in a traditional perspective the satisfaction is measured from the extent to which consumers perceive or perceive psychologically the conditions such as feeling happy, comfortable and at home and the freedom of the problem faced by consumers (Ruly, 2011)
It is supported by Vera (2015), that the whole perception of quality Products can be an important element to create a positive effect on Customer value. The effect of product quality on customer value is moderated by Factors such as interest in products, the interests of a product, the perception Perception of happiness, product symbolism, customer satisfaction, interest behaviour, Brand leadership. Interest in a product and the factor of happiness is The moderation involved is very signifan in influencing the positive relationship between the quality Product and customer value (Hendy, 2016)

Satisfaction is a comparison between ExPEC-Tasi and performance. Dissatisfaction OC-curred when the performance falls short ExPEC-Tasi. Satisfaction occurs when performance matches or exceeds expectations (Kotler \& Philip, 2010). Satisfaction is how far the customer needs, wishes, and expectations are fulfilled (Cannon et al, 2009).

Belief is the belief of the parties that the other party will conduct a transaction in accordance with the former-pectation of the first party, in the uncertain circumshot-attitude (BA \& Pavlou, 2002). The customer trust in e-commerce settings is the CUS-net willingness to trust an e-commerce website (Murphy and Blessinger, 2003). Customer loyalty is a COMPuan service for using goods or services in the future (Kotler and Keller, 2006). In e-commerce con-text, customer loyalty intention to buy from e-commerce websites and intention not to switch to other websites that offer similar of-ferings (Flavián, Guinalíu, and Gurrea, 2007).

\section{RESEARCH METHODS}

Research is done using a Deskriftif method with a quantitive approach. This assessment is done to determine the influence and relationship between variables. Emphasizing a quantitative approach, the study explains the partial and simultaneous influences between marketing culture variables (X1), competative Excellence (X2), and consumer attitudes (y1). The research uses primary data obtained from questionnaires distributed to 75 entrepreneurs affected by COVID-19. This study uses multiple regression analyses. This analysis is used to measure the strength of two or more variables and also indicate the direction of the relationship between dependent variables and independent variables. Data collected, then processed and also analyzed using SPSS version 16.0. The data analysis techniques used are as follows:

\section{A. Validity test}

The validity test is used to test which questionnaire items are valid and invalid (Maida, 2017). The validity test in this study was conducted by comparing the arithmetic value of $\mathrm{R}$ with the table $\mathrm{R}$. If the value of $\mathrm{R}$ Count is higher than $\mathrm{R}$ table, then the question is valid.

\section{B. Reliability Test}

The reliability test is used to demonstrate the reliability level of internal consistency by measuring the coefficient of Alfa Cronbach, where variables can be categorized as reliable if they have an alpha value higher than 0.60 (Riyanto, 2019). 


\section{Multiple linear regression analyses}

This analysis is used to determine the direction of the relationship between dependent and independent variables, whether each variable is independent positive or negative, and to predict the value of the dependent variable when there is an increase or decrease in an independent variable (Maida, 2017).

\section{RESEARCH RESULTS}

The validity of each question posed to the respondent. Output stated that all the variables in the research have valid, which all value already above $r$ table $(r=0,2272)$. From this, it is also a known description of the characteristics of respondents on research as follows:

\begin{tabular}{|c|c|c|}
\hline Description & Type & Amount \\
\hline Gender & Man & 60 \\
\hline & Woman & 15 \\
\hline Education & High School & 27 \\
\hline & Diploma & 5 \\
\hline & Bachelor & 33 \\
\hline Age & Master & 10 \\
\hline & $20-30$ Years & 34 \\
\hline Income & $\begin{array}{c}31-40 \text { Years } \\
41-50 \text { Years }\end{array}$ & 16 \\
\hline & $\begin{array}{c}\text { Rp. } 5.100 .000,000,00 \\
10.000 .000,00\end{array}$ & 14 \\
\hline & Rp. $10.100 .000,00-$ Rp. \\
$15.000 .000,00$ & 32 \\
\hline & $\begin{array}{c}\text { Rp.15.100.000,00- Rp. } \\
20.000 .000,00\end{array}$ & 20 \\
\hline
\end{tabular}

Table 1:- Description of Research Objective

a.Source: Data Processing Results SPSS 1.6

The results of data processing and discussion in this study were obtained from the dissemination of questionnaires to 75 entrepreneur as primary data. This prisoner consists of 38 question items outlined based on several variables to be researched, i.e., the effect of using Sales Culture (X1) and competitive advantage (X2) on consumer behavior (Y).

Based on table 2 can be seen that with a significant rate of 5\%, 75 respondents acquired $\mathrm{R}$ table 0.2272 . In such tables, the validity test for the $\mathrm{X} 1$ variable that is Sales Culture indicates that all query items have a value of $\mathrm{R}$ Count greater than 0297, which means it is valid or feasible to be used for research. The validity test for a variable $\mathrm{X} 2$ that is a competitive advantage variable shows all query items have a value of R Count greater than 0297, which means it is valid or feasible to be used for research.

\begin{tabular}{|c|c|c|c|}
\hline Variables & $\begin{array}{c}\text { The range of } \\
\text { value } \\
\text { (r count) }\end{array}$ & Requirement & Dese \\
\hline $\begin{array}{c}\text { Sales Culture } \\
\left(\mathrm{X}_{1}\right)\end{array}$ & $0.485-0.725$ & 0.2272 & Valid \\
\hline $\begin{array}{c}\text { Competitive } \\
\text { Advantage }\left(\mathrm{X}_{2}\right)\end{array}$ & $0.599-0.841$ & 0,2272 & Valid \\
\hline $\begin{array}{c}\text { Consumer } \\
\text { Behavior }(\mathrm{Y})\end{array}$ & $0.412-0.778$ & 0,2272 & Valid \\
\hline
\end{tabular}

Table 2:- Analysis of Correlation Variables

b.Source: Data Processing Results SPSS 1.6

\section{A. Reliability Test}

The reliability test in the study was done by looking at the value of Cronbach Alpha. An instrument is said to be reliable when the alpha coefficient has a value greater than 0.60 . The result of the reliability of the results of all variables in this study can be seen in Table 3.

\begin{tabular}{|c|c|c|c|}
\hline Variable & $\begin{array}{c}\text { Reliability } \\
\text { Coefficient }\end{array}$ & $\begin{array}{c}\text { Critical } \\
\text { Value }\end{array}$ & Description \\
\hline $\begin{array}{c}\text { Sales Culture } \\
\left(\mathrm{X}_{1}\right)\end{array}$ & 0.600 & 0.6 & Reliable \\
\hline $\begin{array}{c}\text { Competitive } \\
\text { Advantage } \\
\left(\mathrm{X}_{2}\right)\end{array}$ & 0.824 & 0.6 & Reliable \\
\hline $\begin{array}{c}\text { Consumer } \\
\text { Behavior }(Y)\end{array}$ & 0.712 & 0.6 & Reliable \\
\hline
\end{tabular}

Table 3:- Reliability Test Results

c.Source: Data Processing Results SPSS 1.6

According to table 3, it can be seen that the use of Sales Culture(X1), Competitive Advantage (X2), and Consumer Behavior (Y) has a coefficient value greater than 0.60 with a value each of 0.600 for a variable use (X1), 0.824 for variables (X2), and 0.712 for variables $(\mathrm{Y})$. This indicates that the question item in each variable can be said to be reliable for measuring the variables.

\section{B. Multiple Linear regression equation analysis}

Multiple linear regression analysis of this regression analysis is used to calculate the magnitude of influence between the use of $\mathrm{X} 1$ and $\mathrm{X} 2$ against variables $\mathrm{Y}$.

\section{Regression equation}

Regression equations are used to know the relationship form between variables. By using the help of SPSS for Windows ver 16.0 get the regression model as in table 4: 
Coefficients $^{\mathrm{a}}$

\begin{tabular}{|l|l|l|l|l|l|l|}
\hline \multicolumn{2}{|l|}{ Model } & Unstandardized Coefficients & Standardized Coefficients & \multirow{2}{*}{ t } & \\
\cline { 3 - 7 } \multicolumn{2}{l|}{} & B & Std. Error & Beta & & \\
\hline \multirow{3}{*}{1} & (Constant) & 9.066 & 2.136 & & 4.245 & .000 \\
\cline { 2 - 7 } & Sales Culture & .187 & .077 & .255 & 2.427 & .018 \\
\cline { 2 - 8 } & Competitive Advantage & .229 & .066 & .362 & 3.451 & .001 \\
\hline
\end{tabular}

Table 4:- Multiple Linear regression analysis results

d. Source: Data Processing Results SPSS 1.6

Output can be illustrated model $\rightarrow \mathrm{Y}=9.066+0.187 \mathrm{X} 1+$ $0.229 \times 2$

Table 4 shows the results of multiple linear regression uses of (X1) obtained a calculated t value of 2,427 and t tables amounting to 1,993 It shows that the $\mathrm{X} 1$ variable has a significant effect on Consumer Behavior as it has a larger counting $t$ than the table. Whereas, the working (X2) obtained a calculated $t$ value of 3.451 and $T$ tables of 1,993 It shows that variable $\mathrm{X} 2$ has a significant effect on Consumer Behavior as it has a larger count than $t$ table.

ANOVA
\begin{tabular}{|c|c|c|c|c|c|c|}
\hline \multicolumn{2}{|c|}{ Model } & $\begin{array}{c}\text { Sum of } \\
\text { Squares }\end{array}$ & df & $\begin{array}{c}\text { Mean } \\
\text { Square }\end{array}$ & F & Sig. \\
\hline \multirow{2}{*}{1} & Regression & 114.899 & 2 & 57.450 & 10.152 & $.000^{\mathrm{a}}$ \\
\cline { 2 - 7 } & Residual & 407.447 & 72 & 5.659 & & \\
\cline { 2 - 7 } & Total & 522.347 & 74 & & & \\
\hline
\end{tabular}

Table 5:- The Result of F-Test

e.Source: Data Processing Results SPSS 1.6

Based on the table above, it can be noted that the value of the calculated $F$ has been obtained by 10.152 , where the value of the $\mathrm{F}$ table is 3.122 This indicates that the sales culture usage variables and the competitive collectively (simultaneous) have a significant effect on the customer behavior due to the value of $\mathrm{F}$ count greater than the table $\mathrm{F}$ value.

\begin{tabular}{|c|c|c|c|c|}
\hline \multicolumn{5}{|c|}{ Model Summary } \\
\hline Model & $\mathrm{R}$ & R Square & $\begin{array}{c}\text { Adjusted R } \\
\text { Square }\end{array}$ & $\begin{array}{c}\text { Std. Error of } \\
\text { the Estimate }\end{array}$ \\
\hline 1 & $.469^{\mathrm{a}}$ & .220 & .198 & 2.379 \\
\hline
\end{tabular}

Table 6:- The Result of The Coefficient of Determination f.Source: Data Processing Results SPSS 1.6

From the table above can be obtained the value of coefficiencies determination as follows:

$$
\begin{aligned}
\mathrm{KD} & =\mathrm{R} 2 \times 100 \% \\
& =(0.469) 2 \times 100 \% \\
& =22 \%
\end{aligned}
$$

This indicates that the Sales Culture (X1) and Competitive Advantage (X2) Usage variables provide a simultaneous effect of $22 \%$ on Consumer Behavior (Y).

The company must activate and manage the consumer behavioral communication strategy to get closer to the type of consumer. Alternative strategies can be used such as reference groups, family members, and opinion leaders. As a consequence, these types of consumers will have a high value of perceived and high satisfaction, so they will have a stronger intention to buy back the product from the company and recommend it to others. Meanwhile, passive consumers, who are less sensitive to the market, can not be sure what they want to do in the future. They lack confidence in deciding whether they will be bought back or not, and lack confidence stating that they will recommend other people's products, however, they are more likely to stick with the current company's ignorance of the market. Therefore, it is important for companies to identify the attitudes of the consumers they serve.

This will help the company to provide a better increase in the level of satisfaction for every consumer behaviour. As a consequence, companies can predict the future behavior of every consumer. In doing so, companies need to strategically create and manage value propositions before delivering the value of consumer segments. By providing better value and satisfaction to certain consumers, the company is motivated to become active in managing value chains and differentiation product points (Yi and Jeon 2003).

They are also motivated to make fundamental decisions on customer segmentation, competence, culture, infrastructure, technology, resources, and strategies (O'Dell and Grayson 1998). If this happens, the company will increase its effectiveness and efficiency in the shipping value. Effectiveness is the ability of the product or service to meet customers ' needs and desires, as well as efficiency means that customers spend minimal casualties (money, time, effort) to receive value (Sheth et al. 1999). As a result, companies can improve their organizational performance.

\section{CONCLUSION}

Based on the results that have been obtained from tabulation by using SPSS program version 16.0 then can be concluded: Sales Culture and Competitive advantage affect an Consumer Behavior. Matches the results obtained against the Sales Culture variables (X1) and the Competitive advantage (X2).

A significant and positive influence on the use of Sales Culture on Consumer Behavior. It is in the prove with the acquisition of the calculated $t$ value of 2,427 and t table of 1,993 . The presence of positivity and significant Competitive advantage on Consumer Behavior. It is evidenced by the acquisition of the $t$ value of the calculated $t$ value of 3,451 and the $t$ table of 1,993 . 
The company must activate and manage the consumer behavioral communication strategy to get closer to the type of consumer. This will help the company to provide a better increase in the level of satisfaction for every consumer behaviour. It can improve the effectiveness and efficiency of the company. Effectiveness is the ability of the product or service to meet customers ' needs and desires.

\section{REFERENCES}

[1]. Riyanto, S., Adonia., Ali, H. (2017), Effect of motivation and job satisfaction on the performance of teachers in Mentari School Bintaro (MSB). International Journal: Scholars Bulletin, 3 (3), 83-91

[2]. Akbar M.M and Parvez. 2009. Impact of Service Quality, Trust, and Customer Satisfaction Loyalty, ABAC Journal, Vol. 29, No.1.Januari, 24-38.

[3]. Townsend,C.M. (2003). Essentials of Psychiatric Mental Health Nursing. (3th edition). Philadelphia: W.B. Saunders Co.

[4]. Rokeach, M. 1973. The Nature of Human Values. New York : The Free Press

[5]. Assael, 2010 Consumer Behavior and Marketing Action.Fifth Edition. Cincinnati Ohio: South-Western College Publishing

[6]. Akbarina , Farida dan Vera Silviana Ehry. 2015. "Pengaruh Citra Perusahaan dan Penanganan Keluhan Terhadap Kepuasan, Kepercayaan Serta Loyalitas Pelanggan (Survei Pada Pelanggan Bengkel Servis Resmi Toyota di Kota Malang)", Jurnal Manajemen Bisnis, Malang : Jurnal Tidak Diterbitkan

[7]. Yi, Y. and Jeon, H. (2003). Programs on Value Perception, Program Loyalty, And Brand Loyalty. Journal of The Academy of Marketing Science, Vol. 35, No. 3, pp. 229-240.

[8]. O'Dell, C. and Grayson, C.J. 1998. If only we knew what we know: the transfer of internal knowledge and best practice. The Free Press, New York.

[9]. Sheth, B. B., Bandelin, F. J., and Shangraw, R. F., 1980, Compresed Tablet in Lachman, L., Lieberman, H. A., and Kanig, J. L., (Editor). Pharmaceutical Dosage Form. Tablets, Vol I, Marcel Dekker Inc., New York. 109, 116, 135- 139.

[10]. Kotler, Philip. 2010. Manajemen Pemasaran. Edisi tiga belas Bahasa Indonesia.Jilid 1 dan 2.Jakarta : Erlangga.

[11]. Cannon, Perreault dan McCarthy. 2009. Pemasaran Dasar Pendekatan Manajerial Global Buku 2 Edisi 16. Jakarta: Salemba Empat

[12]. Ba, S. dan Pavlou P. A. 2002. Evidence of the Effect of Trust Building Technology in Electronic Markets: Price Premiums and Buyer Behavior. MIS quarterly vol. 26 no. 3 , pp. $243-268$

[13]. Flavián, Guinalíu, dan Gurrea . 2007 "Perceived eservice quality (PeSQ): Measurement validation and effects on consumer satisfaction and web site loyalty", Managing Service Quality: An International Journal, Vol. 17 Issue: 3, pp.317-340 